\title{
HUBUNGAN ANTARA POLA ASUH ORANG TUA DENGAN KESEHATAN MENTAL ANAK KELAS 5 DAN 6 DI SDN 01 NGOMBAKAN KECAMATAN POLOKARTO KABUPATEN SUKOHARJO
}

\author{
Budi Kristanto ${ }^{1}$, Bagus Tesar Yunanto ${ }^{2}$
}

\begin{abstract}
Based Health Research (Riskesdas) in 2007, the national prevalence of mental emotional disorder in the population aged $\geq 15$ years was $11.6 \%$. The data indicate the numbers are quite large. Based on the observations of researchers one of the things that potentially associated with children's mental health is the parents' parenting.

This study aimed to determine the relationship of parenting parents with mental health Grade 5 and 6 at SDN 01 Ngombakan Polokarto District of Sukoharjo district.

Results of this research are (1) 34 respondents (74\%) with democratic parenting, while 12 parents of respondents (26\%) with the authoritarian parenting, and no parents with permissive parenting. (2) a total of 27 respondents $(58 \%)$ in a healthy mental state, while 19 respondents $(42 \%)$ in an unhealthy mental state.

The conclusion with Pearson Chi-Square is 0.0379 , where <of $\alpha$ : 0:05. It can be concluded that there is a relationship between parenting parents with mental health Grade 5 and 6 at SDN 01 Ngombakan Polokarto District of Sukoharjo district.
\end{abstract}

Keywords: Parenting, Mental Health, School Age

\section{PENDAHULUAN}

Masalah kesehatan mental yang terjadi pada remaja semakin tahun semakin meningkat. Menurut WHO (2014), seperti yang dikutip oleh Andania (2015) Sebesar 45\% remaja mengalami gangguan mental seperti depresi, gangguan mood dan substance abuse. Pola pengasuhan terhadap anak adalah salah satu faktor yang sangat mempengaruhi bagaimana masa depan anak nantinya. Sebagai orang tua sering kali tidak menyadari bahwa tahuntahun pertama kehidupan anak merupakan waktu yang sangat menentukan dalam hal tumbuh kembang fisik, mental, dan psikososialnya. Hal tersebut berjalan begitu cepat sehingga keberhasilan tahun-tahun pertama dalam hal pengasuhan anak sangat besar pengaruhnya terhadap hari depan anak. (Ananda, 2011)

Bentuk pola asuh orang tua terhadap anak merupakan interaksi antara anak dan orang tua selama mengadakan kegiatan pengasuhan, mendidik, membimbing, dan mendisiplinkan serta melindungi anak untuk mencapai kedewasaan sesuai dengan norma-norma yang berlaku di masyarakat. Pola asuh sangat mempengaruhi peran dan fungsi keluarga. Pengasuhan keluarga dalam pembentukan dan perkembangan kepribadian anak sangat besar karena keluarga merupakan sosial yang pertama dimana anak berinteraksi, tempat anak belajar, dan menyatakan dirinya sebagai makhluk sosial. (Gunarsa, 2008) Keluarga juga dapat memberikan dasar pembentukan tingkah laku, watak, moral, dan pendidikan kepada anak. Suatu keluarga ditandai dengan adanya orang tua, baik ayah maupun ibu. Orang tua sebagai koordinator keluarga harus berperilaku proaktif, jika anak menentang otoritas, segera 
ditertibkan karena dalam keluarga terdapat aturan-aturan. (Kartono, 2010)

Berdasarkan Riset Kesehatan Dasar (Riskesdas) pada tahun 2007, prevalensi nasional gangguan mental emosional pada penduduk yang berumur $\geq 15$ tahun adalah $11,6 \%$. Terjadi penurunan prevalensi gangguan emosional dari 11,6 persen pada tahun 2007 , menjadi 6,0 persen pada tahun 2013. Akan tetapi data gangguan mental emosional untuk usia kurang dari 15 tahun tidak dipaparkan pada penelitian ini.

Menurut Menninger sebagaimana dikutip oleh Lukluk dan Bandiyah (2008), sehat mental adalah penyesuaian manusia terhadap lingkungannya dan orang-orang lain dengan keefektifan dan kebahagiaan yang optimal. Dalam mental yang sehat terdapat kemampuan untuk memelihara inteligensi yang siap digunakan, perilaku yang dipertimbangkan secara sosial, dan diposisi yang bahagia.

Dari hasil observasi awal yang penulis lakukan pada 5 orang siswa kelas 5 dan 6 di SDN 01 Ngombakan Kecamatan Polokarto Kabupaten Sukoharjo didapatkan hasil, 1 orang siswa sering membolos, suka berkelahi serta prestasi belajarnya kurang baik, nilainya di bawah batas tuntas. Dari hasil wawancara pada anak tersebut, ternyata orang tuanya sering memarahinya. Sementara itu 4 siswa yang lain rajin, dan sopan, prestasi belajarnya cukup baik dan nilainya di atas batas tuntas. Dari hasil wawancara dari ke empat siswa tersebut, orang tuanya sangat peduli, perhatian. Dari hasil tersebut menunjukkan pola asuh orang tua berbeda-beda. Hal tersebut penting, untuk mengetahui pola asuh yang berbeda-beda bisa mempengaruhi kesehatan mental anak.
Berdasarkan uraian latar belakang di atas, maka peneliti tertarik untuk melakukan penelitian tentang "Hubungan Pola Asuh Orang Tua dengan Kesehatan Mental Anak Kelas 5 dan 6 di SDN 01 Ngombakan Kecamatan Polokarto Kabupaten Sukoharjo".

\section{TUJUAN PENELITIAN}

1. Untuk mengetahui hubungan pola asuh orang tua dengan kesehatan mental anak kelas 5 dan 6 di SDN 01 Ngombakan Kecamatan Polokarto Kabupaten Sukoharjo.

2. Untuk mengetahui macammacam pola asuh orang tua anak kelas 5 dan 6 SDN 01 Ngombakan Kecamatan Polokarto Kabupaten Sukoharjo.

3. Untuk mengetahui kesehatan mental pada anak kelas 5 dan 6 SDN 01 Ngombakan Kecamatan Polokarto Kabupaten Sukoharjo.

\section{DESAIN PENELITIAN}

Penelitian ini merupakan penelitian analitik dengan desain korelasi untuk mengetahui hubungan pola asuh orang tua sebagai variabel bebas (independent variable) dengan kesehatan mental anak sebagai variabel terikat (dependent variable).

\section{POPULASI, SAMPEL, DAN TEHNIK SAMPLING}

Populasi pada penelitian ini adalah seluruh siswa kelas 5 dan 6 di SDN 01 Ngombakan Kecamatan Polokarto Kabupaten Sukoharjo yang berjumlah 46 anak.

Sampel pada penelitian ini adalah seluruh populasi yaitu siswa kelas 5 dan 6 di SDN 01 Ngombakan Kecamatan Polokarto Kabupaten Sukoharjo sebanyak 46 anak. 
HASIL PENELITIAN

1. Karakteristik Responden

Tabel 1.

Karakteristik Responden

\begin{tabular}{lccc}
\hline Karakteristik & Kategori & $\mathrm{n}$ & $\%$ \\
\hline Jenis kelamin & Laki-laki & 25 & 54 \\
& Perempuan & 21 & 46 \\
Usia (tahun) & 10 & 5 & 11 \\
& 11 & 24 & 52 \\
& 12 & 15 & 33 \\
& 13 & 1 & 2 \\
Tingkat & 14 & 1 & 2 \\
pendidikan & Tidak & 14 & 30 \\
orang tua & menjawab & & \\
& SD & 5 & 11 \\
& SMP & 8 & 17 \\
Pekerjaan & SMA & 17 & 37 \\
orang tua & S1 & 2 & 5 \\
& Ibu rumah & 2 & 4 \\
& tangga & 2. & \\
& Swasta & 19 & 41 \\
& Wiraswasta & 16 & 35 \\
& Pedagang & 2 & 4 \\
& Petani & 5 & 11 \\
& PNS/TNI & 2 & 4 \\
\hline
\end{tabular}

Dari tabel di atas diperoleh informasi bahwa responden pada penelitian ini lebih banyak berjenis kelamin laki-laki dengan jumlah 25 (54\%) dibandingkan responden perempuan dengan jumlah 21 (46\%).

Dari usia paling mendominasi adalah usia 11 tahun yaitu sejumlah 24 responden (52\%), menyusul usia 12 tahun sejumlah 15 responden (33\%), usia 10 tahun sejumlah 5 responden $(11 \%)$, usia 13 dan 14 tahun masing-masing 1 responden atau $2 \%$

Sedangkan karakteristik pendidikan orang tua responden sejumlah 17 (37\%) berpendidikan SMA dan hanya 2 orang tua responden berpendidikan sarjana.

Sedangkan dari karakteristik pekerjaan orang tua, sejumlah 19 (41\%) pekerjaannya adalah swasta dan sejumlah 16 (35\%) berwiraswasta.
2. Pola Asuh Orang Tua

Tabel 2

Distribusi Frekuensi Pola Asuh pada Orang Tua

\begin{tabular}{ccc}
\hline Pola Asuh & $f$ & $\%$ \\
\hline Otoriter & 12 & 26 \\
Permisif & 0 & 0 \\
Demokratis & 34 & 74 \\
\hline Jumlah & 46 & 100
\end{tabular}

Dari tabel di atas dapat diperoleh bahwa mayoritas orang tua responden yaitu sejumlah 34 (74\%) dengan pola asuh demokratis, sedangkan 12 orang tua responden $(26 \%)$ dengan pola asuh otoriter, dan tidak ada orang tua dengan pola asuh yang dominan adalah permisif.

3. Kesehatan Mental

Tabel 3

Distribusi Frekuensi Kesehatan Mental Responden

\begin{tabular}{ccc}
\hline Pola Asuh & $f$ & $\%$ \\
\hline Sehat & 27 & 58 \\
Kurang sehat & 19 & 42 \\
\hline Jumlah & 46 & 100 \\
\hline
\end{tabular}

Dari tabel di atas jelas terlihat bahwa mayoritas responden dalam keadaan mental yang sehat, yaitu sejumlah 27 responden $(58 \%)$, sedangkan 19 responden $(42 \%)$ dalam keadaan kurang sehat mental.

4. Hasil Analisa Univariat Kesehatan Mental Anak

Tabel 4

Hasil Analisa Univariat

Kesehatan Mental Anak

\begin{tabular}{cc}
\hline $\mathrm{N}$ & 46 \\
\hline Mean & 79.56 \\
Median & 87.5 \\
Modus & 90 \\
Std. Dev & 14.86
\end{tabular}

Dari data di atas tampak bahwa mean (rata-rata) kesehatan mental dari responden adalah 79,56 yang menunjukkan kesehatan mental responden pada kategori sehat, demikian pula dengan median yaitu 87,5 yang menunjukkan nilai tengah data dari data nilai kesehatan 
mental responden adalah sehat. Sedangkan diperoleh modus 90 yang bermakna bahwa data yang sering muncul menunjukkan kondisi sehat mental

5. Hubungan Pola Asuh terhadap Kesehatan Mental Anak

Tabel 5. Hasil Uji Chi Square

\begin{tabular}{|c|c|c|}
\hline & Df & $\begin{array}{l}\text { Asymp. Sig. } \\
\text { (2-sided) }\end{array}$ \\
\hline PearsonChiSquare & 1 & 0.0379 \\
\hline Likelihood Ratio & 1 & 0.0383 \\
\hline & & 0.0400 \\
\hline $\mathrm{N}$ of Valid Cases & & 46 \\
\hline $\begin{array}{l}\text { Dengan meliha } \\
\text { didapatkan bah } \\
\text { Pearson Chi- } \\
0.0379 \text {, dimana } \\
\text { Maka dapat dis } \\
\text { terdapat hubun } \\
\text { asuh orang } \\
\text { kesehatan ment } \\
\text { dan } 6 \text { di SDN } \\
\text { Kecamatan Polo } \\
\text { Sukohario. }\end{array}$ & $\begin{array}{l}\text { Squar } \\
\mathrm{p}<\mathrm{d} \\
\text { simpul } \\
\text { gan a } \\
\text { tua } \\
\text { tal an }\end{array}$ & $\begin{array}{l}\text { ta di atas, } \\
\text { nilai p uji } \\
\text { re adalah } \\
\text { lari } \alpha: 0.05 \text {. } \\
\text { lkan bahwa } \\
\text { antara pola } \\
\text { nak dengan } \\
\text { nak kelas } 5 \\
\text { Ngombakan }\end{array}$ \\
\hline
\end{tabular}

\section{PEMBAHASAN}

1. Pola Asuh Pada anak kelas 5 dan 6 di SDN 01 Ngombakan Kecamatan Polokarto Kabupaten Sukoharjo

Dari penelitian ini dapat diperoleh bahwa mayoritas orang tua responden yaitu sejumlah 34 (74\%) dengan pola asuh demokratis, sedangkan 12 orang tua responden (26\%) dengan pola asuh otoriter, dan tidak ada orang tua dengan pola asuh yang dominan adalah permisif.

Pola asuh merupakan sikap orang tua dalam berinteraksi dengan anak-anaknya. Sikap orang tua ini meliputi cara orang tua memberikan aturan-aturan, hadiah maupun hukuman, cara orang tua menunjukkan otoritasnya dan juga cara orang tua memberikan perhatian serta tanggapan terhadap anak. Kohn dalam Habibi (2015), menjelaskan bahwa pola asuh merupakan proses interaksi antara anak dengan orang tua dalam pembelajaran dan pendidikan yang nantinya sangat bermanfaat bagi aspek pertumbuhan dan perkembangan.

Melihat hasil yang diperoleh pada penelitian ini menunjukkan bahwa mayoritas orang tua responden yaitu sejumlah 34 $(74 \%)$ dengan pola asuh demokratis yaitu orang tua sangat memperhatikan kebutuhan anak, dan mencukupi dengan pertimbangan faktor kepentingan dan kebutuhan. 12 orang tua responden (26\%) yang lain menerapkan pola asuh otoriter, pola ini menggunakan pendekatan yang memaksa kehendak orang tua kepada anak. Anak harus menurut pada orang tua. Keninginan orang tua harus dituruti, anak tidak boleh mengeluarkan pendapat. (Habibi, 2014)

Pada penelitian ini tidak terdapat orang tua yang lebih dominan melakukan pola asuh yang permisif. Namun demikian, setiap kesimpulan pola asuh ini diperoleh dengan melihat ciri dominan dalam melaksanakan pola asuh, dan tidak didapatkan orang tua yang melakukan pola asuh yang mutlak pada salah satu jenis pola asuh yang ada.

2. Kesehatan mental anak kelas 5 dan 6 di SDN 01 Ngombakan Kecamatan Polokarto Kabupaten Sukoharjo

Dari penelitian ini terlihat bahwa mayoritas responden dalam keadaan mental yang sehat, yaitu sejumlah 27 responden (58\%), sedangkan 19 responden (42\%) dalam keadaan kurang sehat mental.

Kesehatan mental adalah pengetahuan dan perbuatan 
yang bertujuan untuk mengembangkan dan memanfaatkan segala kapasitas, kreativitas, energi, dan dorongan yang ada semaksimal mungkin sehingga membawa kepada kebahagiaan diri dan orang lain serta terhindar dari gangguan atau penyakit mental (neurosis dan psikosis). (Semiun, 2006)

Pada penelitian ini didapatkan hasil bahwa mayoritas responden dalam keadaan mental yang sehat, yaitu sejumlah 27 responden (58\%), sedangkan 19 responden $(42 \%)$ dalam keadaan kurang sehat mental. Parameter yang digunakan menggunakan sehat dan kurang sehat, peneliti menggunakan penilaian kesehatan mental dengan kategori sehat skor 75 s.d 100 sedangkan kurang sehat skor kurang dari atau sama dengan 70.

Namun demikian hasil uji univariat menunjukkan bahwa mean (rata-rata) kesehatan mental dari responden adalah 79,56 yang menunjukkan kesehatan mental responden pada kategori sehat, demikian pula dengan median yaitu 87,5 yang menunjukkan nilai tengah data dari data nilai kesehatan mental responden adalah sehat. Sedangkan diperoleh modus 90 yang bermakna bahwa data yang sering muncul menunjukkan kondisi sehat mental.

Dimana menurut Killander sebagaimana dikutip oleh Lukluk dan Bandiyah (2008), ciri-ciri sehat mental ada empat yaitu:

a. Kematangan emosional terdapat tiga dasar emosi yaitu: cinta, takut, dan marah. Terdapat tiga ciri perilaku dan pemikiran pada orang yang emosinya matang, yaitu memiliki disiplin diri, determinasi diri dan kemandirian. Seseorang yang memiliki disiplin diri dapat mengatur diri, hidup teratur, mentaati hukum dan peraturan. Orang yang memiliki determinasi diri akan dapat membuat keputusan dalam memecahkan masalah.

b. Kemampuan menerima realita : adanya perbedaan antara dorongan, keinginan dan ambisi di satu pihak serta peluang dan kemampuan di pihak lain, adalah hal yang biasa terjadi. Orang yang mempunyai kemampuan realita antara lain mampu memecahkan masalah dengan segera dan menerima tanggung jawab. Bahkan kalau mungkin tidak sulit untuk menyesuaikan diri dengan lingkungan terbuka untuk pengalaman dan gagasan baru, membuat tujuan yang realistis, dan melakukan yang terbaik sampai merasa puas atas hasil usaha tersebut.

c. Hidup bersama dan bekerja sama dengan orang lain : hal ini menyangkut hakekat sebagai makhluk sosial yang tidak sekedar mau dan bersedia serta mampu bekerjasama untuk mencapai prestasi yang lebih tinggi dari pada dikerjakan sendiri, melainkan juga karena tidak dapat bertahan hidup sendiri.

d. Memiliki sifat atau pandangan hidup : yang dimaksud memiliki pandangan hidup adalah memiliki pegangan hidup yang dapat senantiasa membimbingnya untuk berada di jalan yang benar.

3. Hubungan antara Pola Asuh Orang Tua dengan Kesehatan Mental Anak Kelas 5 dan 6 di SDN 01 Ngombakan Kecamatan Polokarto Kabupaten Sukoharjo Dari hasil analisis Chi-Square diperoleh nilai p 0.0379, dimana 
$p<\alpha$ : 0.05. Maka dapat disimpulkan bahwa terdapat hubungan antara pola asuh orang tua dengan kesehatan mental anak kelas 5 dan 6 di SDN 01 Ngombakan Kecamatan Polokarto Kabupaten Sukoharjo. Hal ini senada dengan penelitian yang dilakukan oleh Aini dan Dewi (2013) bahwa terdapat hubungan yang siknifikan antara pola asuh orang tua dengan penyimpangan anak.

Menurut Kartono (2009), beberapa faktor yang sangat menentukan dalam usaha mencapai mental yang sehat dan adjusment serta adaptasi pada lingkungan ialah:

a. Kondisi dan konstitusi fisiknya, yang menjadi faktor penentu herediter (hereditair determinant), sistem persyarafan, sistem kelenjar, sistem otot, kesehatannya (dalam keadaan sakit atau sehat).

b. Kematangan taraf pertumbuhan dan perkembangannya, terutama faktor intelek, kematangan sosial dan moral, serta kematangan emosionalnya.

c. Derterminan psikologis, yaitu berupa: pengalamanpengalaman, trauma-trauma, situasi-situasi dan kesulitan belajar, kebiasaan-kebiasaan, penentuan diri (self determination), frustasifrustasi, konflik-konflik, dan saat-saat kritis.

d. Kondisi lingkungan dan alam sekitar: misalnya keluarga/ rumah tangga, famili, sekolah, lingkungan kerja, temanteman dan lain-lain.

Hasil penelitian ini membuktikan bahwa kondisi lingkungan keluarga, terutama pola asuh berhubungan dengan kesehatan mental dari anak. Pada penelitian ini mayoritas anak dalam rentang
Usia 10 - 12 tahun, dan masingmasing 1 anak dengan usia 13 dan 14 tahun.

Menurut Tridhonanto (2014), pada usia ini teman sangat penting dan ketrampilan sosial anak semakin berkembang. Hubungan anak menjadi lebih baik dalam berteman, anak juga mudah untuk mendekati teman baru dan menjaga hubungan pertemanan yang sudah ada. Pada usia ini anak juga menyukai kegiatan kelompok dan petualangan, keadaan ini terjadi karena terbentuknya identifikasi peran dan keberanian untuk mengambil resiko. Orang tua perlu membimbingnya agar anak memahami kemampuan yang sebenarnya dan tidak melakukan tindakan yang berbahaya.

Anak pada usia ini mulai tertarik dengan masalah seks, sehingga orang tua perlu untuk memberikan informasi yang dianggap sensitif ini secara benar. Anak mulai melawan orang tuanya, anak menjadi suka berargumentasi dan tidak suka melakukan pekerjaan rumah. Sebagai orang tua perlu secara bijaksana menjelaskan pada anak mengenai tugas dan tanggung jawabnya. Keberhasilan pada masa kanakkanak akan terlibat jika anak dapat berkarya dan produktif dikemudian hari.

\section{KESIMPULAN}

1. Dari hasil penelitian ini diperoleh bahwa mayoritas orang tua responden yaitu sejumlah 34 (74\%) dengan pola asuh demokratis, sedangkan 12 orang tua responden (26\%) dengan pola asuh otoriter, dan tidak ada orang tua dengan pola asuh permisif.

2. Dari hasil penelitian ini diperoleh bahwa mayoritas responden dalam keadaan mental yang 
sehat, yaitu sejumlah 27 responden (58\%), sedangkan 19 responden $(42 \%)$ dalam keadaan kurang sehat mental.

3. Dari analisis univariat tampak bahwa mean (rata-rata) kesehatan mental dari responden adalah 79,56 yang menunjukkan kesehatan mental responden pada kategori sehat, demikian pula dengan median yaitu 87,5 yang menunjukkan nilai tengah data dari data nilai kesehatan mental responden adalah sehat. Sedangkan diperoleh modus 90 yang bermakna bahwa data yang sering muncul menunjukkan kondisi sehat mental.

4. Hasil analisis Chi-Square diperoleh nilai $p$ adalah 0.0379 , dimana $p<$ dari $\alpha: 0.05$. Maka dapat disimpulkan bahwa terdapat hubungan antara pola asuh orang tua dengan kesehatan mental anak kelas 5 dan 6 di SDN 01 Ngombakan Kecamatan Polokarto Kabupaten Sukoharjo.

\section{SARAN}

1. Bagi masyarakat secara umum dan khususnya orang tua yang memiliki anak usia sekolah, memahami bahwa terdapat hubungan antara pola asuh yang diterapkan dengan kesehatan mental anak, yang akan berdampak pada perkembangan serta prestasi belajar. Karenanya masyarakat bisa menerapkan pola asuh yang tepat.

2. Bagi profesi perawat dapat memberikan anjuran kepada orang tua pada saat melakukan edukasi kepada masyarakat terkait dengan kesehatan mental anak, yang salah satunya dipengaruhi oleh pola asuh orang tua.

3. Bagi peneliti selanjutnya dapat menggunakan hasil penelitian ini sebagai data awal untuk melakukan

penelitian

selanjutnya.

\section{DAFTAR PUSTAKA}

Ananda, R. 2011. Membangun Karakter Positif Buah Hati. Razan Media Press, Jakarta.

Kartono, K. 2009. Psikologi Abnormal dan Abnormalitas Seksual. CV. Mandar Maju, Bandung.

Lukluk A, Z. dan Bandiah, S. 2008. Psikologi Kesehatan. Mitra Cendikia Press, Yogyakarta.

Septiari, B. B. 2012. Mencetak Balita Cerdas dan Pola Asuh Orang Tua. Nuha Medika, Yogyakarta.

Semiun, Y. 2006. Kesehatan Mental 1. Kanisius, Yogyakarta.

Siswanto. 2007. Kesehatan Mental: Konsep, Cakupan, dan Perkembanganya. Andi Offset, Yogyakarta,.

Tridhonanto, A. L. 2014. Mengembangkan Pola Asuh Demokratis. PT Elek Media Komputindo, Jakarta.

Gunarsa, D.S. 2008. Dasar dan teori Perkembangan Anak. PT EBK Gunung Mulia, Jakarta.

Andania, N. 2015. Hubungan pola asuh orang tua dengan kesehatan mental remaja di SMKN 5 Padang tahun 2015. http://scholar.unand.ac.id/id/ep rint/2464. Diunduh 5 Oktober 2015.

Aini, L. N. dan Dewi, A. L. 2013. Hubungan Antara Pola Asuh Orang Tua dengan Penyimpangan Mental Emosi Anak Usia 36-72 Bulan di PGTK Gabugan Tanon Sragen. jurnal.akbidmu.ac.id/index.php/jurnalmus/ article/download/59/46.

Diunduh 5 Oktober 2015.

${ }^{1}$ Dosen Akper Panti Kosala

Surakarta

${ }^{2}$ Mahasiswa Akper Panti Kosala Surakarta 